\title{
Establishment and Implementation Approach of Full-course Developmental Employment Guidance Mode in Applied Undergraduate Colleges
}

\author{
Yali Dai \\ Chongqing University of Education, Chongqing, 400065, China
}

Keywords: employment guidance; full-course; developmental

\begin{abstract}
This paper establishes a full-course developmental employment guidance mode focusing on the integrated development of students under the guidance of career guidance theory, which is phased, highlights key points, connection and process and runs through the college life. It aims at excavating subjective development and individual growth needs of students, comprehensively improving students' employment ability and promoting the realization of technical and skilled talent training objective in applied undergraduate colleges.
\end{abstract}

\section{Introduction}

With economic and social transformation and constant deepening of the reform of higher education, the society has higher and higher requirements for talents and traditional employment guidance mode is challenged as it cannot meet the growth need of college students due to its short-term objectives, simple contents, single way and centralized time. Under the historical background of popularization of higher education, the reform of employment guidance mode updating the work idea of employment guidance and changing the way of employment work guidance becomes a rational choice and inevitable trend.

\section{Connotations of full-course developmental employment guidance mode}

Full-course developmental employment guidance mode provides students with employment guidance contents beginning with occupational enlightenment and exploration, including professional career planning, academic career planning, preparation of vocational ability, career choice, self-employment and job training, and considers career choice and the acquisition and development of vocational ability as a long-term and continuous developmental process under the guidance of "people-oriented", "multiple intelligence” and "career guidance” educational concepts with the objective of pursuing and realizing students' integrated development by focusing on college students, following the law of education, paying attention to individual characteristics, needs and growth path of each student and exploring students' subjective and initiative development. Therefore, full-course developmental employment guidance is phased and highlights key points, connection and process. It implements education and guidance throughout the college life of students in steps and pursues for all-round and sustainable development of students.

\section{Systematic frame of full-course developmental employment guidance mode}

The frame system of full-course developmental employment guidance mode in applied undergraduate colleges is put forward under the guidance of career guidance theory and the objective of training technical and skilled talents with good professional ethics and cultural awareness, solid specialty foundation and strong innovation consciousness and practical ability.

\section{(I) Theoretical basis}

The earliest professional career guidance originated from America in early $20^{\text {th }}$ century and has experienced three stages - vocational guidance, vocational counseling and career counseling. Early vocational guidance mainly assists individuals in career choice, employment preparation and adaptation after job placement and employment. In 1909, trait-factor theory of Parsons put forward 
the concept of "person-position fit" and considered that the understanding of hobby and ability, understanding of working environment and nature and their coordination and matching were three principles of vocational counseling. ${ }^{[1]}$ Then, six typical occupational environments and individual types put forward in typology theory established by John Holland have provided an effective scientific and theoretical basis for "person-position fit”. In 1950s, career counseling theory of Super considered that the process of career development was divided into five periods - growth period, exploration period, establishment period, maintenance period and exit period and each period had its unique responsibilities and role and different development tasks. The degree of readiness of individuals in facing and accomplishing development tasks reflects individual career maturity. Maturity can be improved through effective career counseling. "Career counseling" theory put forward by Super which assists individuals in establishing and developing self-concept with appropriate integration and corresponding career choice and mode of life emphasizes development and exploration, pays attention to the training and development of individual career knowledge, skills and concepts and aims at helping individuals realize career maturity. ${ }^{[2]}$

\section{(II) Frame content}

According to career development theory, full-course developmental employment guidance divides the college life of students into three stages - career exploration period, career preparation period and career practice period, which respects the basic law of talent growth and adapts to the training objective of applied technical and skilled talents in applied undergraduate colleges.

\begin{tabular}{|c|c|c|c|c|}
\hline Stage & $\begin{array}{l}\text { Emphasis of } \\
\text { employment } \\
\text { guidance }\end{array}$ & Specific guidance contents & $\begin{array}{c}\text { Way of } \\
\text { employ } \\
\text { ment } \\
\text { guidanc } \\
\text { e } \\
\end{array}$ & $\begin{array}{c}\text { 时间 } \\
\text { Time of } \\
\text { employme } \\
\text { nt } \\
\text { guidance }\end{array}$ \\
\hline \multirow{5}{*}{$\begin{array}{l}\text { Career } \\
\text { explorat } \\
\text { ion } \\
\text { period }\end{array}$} & \multirow{2}{*}{$\begin{array}{l}\text { Professional } \\
\text { enlightenment } \\
\text { education }\end{array}$} & Specialty introduction & \multirow{2}{*}{$\begin{array}{l}\text { Course } \\
\text { Lecture } \\
\text { Case }\end{array}$} & \multirow{5}{*}{$\begin{array}{l}\text { Freshman } \\
\text { year }\end{array}$} \\
\hline & & Professional ideal education & & \\
\hline & \multirow{3}{*}{$\begin{array}{c}\text { 职业生涯规划 } \\
\text { Professional } \\
\text { career planning }\end{array}$} & $\begin{array}{c}\text { Self-knowledge and } \\
\text { exploration }\end{array}$ & \multirow{3}{*}{$\begin{array}{l}\text { Course } \\
\text { Case } \\
\text { Group } \\
\text { guidance }\end{array}$} & \\
\hline & & $\begin{array}{l}\text { Occupational understanding } \\
\text { and requirements }\end{array}$ & & \\
\hline & & $\begin{array}{l}\text { Professional career } \\
\text { decision-making and } \\
\text { management }\end{array}$ & & \\
\hline \multirow{5}{*}{$\begin{array}{c}\text { 职业准 } \\
\text { 备期 } \\
\text { Career } \\
\text { preparat } \\
\text { ion } \\
\text { period }\end{array}$} & \multirow{2}{*}{$\begin{array}{c}\text { 职业素养指导 } \\
\text { Professional } \\
\text { quality guidance }\end{array}$} & $\begin{array}{l}\text { Basic quality training and } \\
\text { guidance }\end{array}$ & \multirow{5}{*}{$\begin{array}{c}\text { Case } \\
\text { Group } \\
\text { guidance } \\
\text { Probatio } \\
\text { n and } \\
\text { internshi } \\
\text { p } \\
\text { Lecture }\end{array}$} & \multirow{5}{*}{$\begin{array}{l}\text { Sophomor } \\
\text { e/junior } \\
\text { year }\end{array}$} \\
\hline & & $\begin{array}{l}\text { Professional quality training } \\
\text { and guidance }\end{array}$ & & \\
\hline & \multirow{3}{*}{$\begin{array}{c}\text { 职业发展辅导 } \\
\text { Career } \\
\text { development } \\
\text { guidance }\end{array}$} & $\begin{array}{c}\text { Guidance on confusions in } \\
\text { career development }\end{array}$ & & \\
\hline & & $\begin{array}{c}\text { Professional career } \\
\text { evaluation and adjustment }\end{array}$ & & \\
\hline & & Career choice guidance & & \\
\hline \multirow{5}{*}{$\begin{array}{l}\text { Career } \\
\text { practice } \\
\text { period }\end{array}$} & \multirow{5}{*}{$\begin{array}{l}\text { Job application } \\
\text { ability training }\end{array}$} & Employment situation & Course & \multirow{5}{*}{ Senior year } \\
\hline & & Job application preparation & Case & \\
\hline & & $\begin{array}{c}\text { Skills and etiquette for job } \\
\text { application }\end{array}$ & $\begin{array}{l}\text { Group } \\
\text { guidance }\end{array}$ & \\
\hline & & $\begin{array}{l}\text { Acquisition and use of } \\
\text { employment information }\end{array}$ & \multirow{2}{*}{$\begin{array}{l}\text { Internshi } \\
\text { p } \\
\text { Lecture }\end{array}$} & \\
\hline & & Employment rights and & & \\
\hline
\end{tabular}




\begin{tabular}{|c|c|c|c|c|}
\hline & & $\begin{array}{c}\text { interests and regulations and } \\
\text { policies }\end{array}$ & \multirow{2}{*}{} & \\
\cline { 2 - 3 } & $\begin{array}{c}\text { Entrepreneurship } \\
\text { education }\end{array}$ & Entrepreneurship preparation & & \\
\hline
\end{tabular}

1. Career exploration period: conduct professional enlightenment education and professional career planning and emphasize "career identity"

The motivation of learning originates from the identification with specialty and career and the willingness to make efforts. Therefore, it is especially important to provide professional enlightenment education for freshmen. Professional enlightenment education includes specialty introduction and professional ideal education. Experts and scholars explain the past , current state and future of specialty development, thus allowing students to understand the relationship between specialty and career and training students' interest and confidence in the specialty. Industry experts and intramural experts are invited to conduct professional ideal education, introduce role models, leading figures and figures with outstanding contributions in professional field, affect students with the power of models and help them set up lofty professional ideals and correct outlook on life, world outlook, value and professional ethics. Professional career planning guidance helps college students to understand themselves, specialty and career, establish an appropriate career development plan according to social development demands and individual interests, abilities and strong points and finally define individual career position and development objectives through scientific and systematic evaluation and consultation.

\section{Career preparation period: conduct professional quality guidance and career development guidance and emphasize "career experience"}

Employment guidance during career preparation period should be integrated with professional learning, daily ideological and political education and management and students' club activities organically. It provides professional quality guidance and career development guidance for sophomores and junior students, leads students to establish good career psychology and concept and good professional quality, conducts effective career evaluation and adjustment and assists them in scientific career choice. Professional quality guidance includes guidance on professional learning and development and basic quality guidance and training, i.e. training of basic qualities of college students such as perfect personality characteristics, cooperative and competitive spirits, communication ability and abilities of writing and language expression and qualities related to the specialty. Career development guidance solves students' various confusions about career development in the planning and implementation process of professional career, allows students to understand the world of work in practice and helps students make career choice through participation in guidance on students' probation and internship.

3. Career practice period: conduct job application ability training and entrepreneurship guidance and emphasize "job application ability"

Applied undergraduate colleges attach great importance to students' practical ability in the positioning of talent training and arrange for senior students to participate in internship and practical educational activities. Therefore, importance is attached to the acquisition of graduates' job application ability, training of their entrepreneurial ability and adaptation and development in career practice in career practice period. Job application guidance and training include methods of collection and screening of job application information, preparation of job application materials, skills in interview and written examination, adjustment of employment psychology and employment policies and regulations etc. Entrepreneurship education includes basic knowledge of entrepreneurship, entrepreneurial approach, environment, quality, risk, policies and practice etc. ${ }^{[3]}$

\section{Path design of full-course developmental employment guidance mode}

\section{(I) Goal pursuit: realize students’ all-round and sustainable development}

Full-course developmental employment guidance mode follows people-oriented educational idea and aims at finally realizing students' all-round and sustainable development. It helps students 
improve self-cognition and evaluation ability, understand specialty and career requirement, define academic and professional objectives and find out approaches for realizing objectives, assists students in realizing their existing academic and professional objectives and allows students to obtain the sense of satisfaction and value in this process through different phased employment guidance contents running through the college life of students.

(II) Team guarantee: professional instructor, internship instructor and employment instructor

The establishment of a team with employment guidance specialization is the guarantee of implementation of full-course developmental employment guidance work. Professional instructor is responsible for students' adaptation to college life, professional quality guidance and professional enlightenment education, guidance on students' professional development by conducting interview or collective guidance, teaching students according to their abilities, helping students establish a study plan, training students' ability of independent study and encouraging and leading students to participate in activities and social practice, and guidance on students' learning from professional and academic perspectives and focuses on professional quality counseling. Internship instructor implements "double instructor" system. Intramural teachers and core teachers in off-campus practice base act as internship instructors and conduct occupational understanding guidance, professional quality guidance and implementation and adjustment in professional career plan in time. Study team or full-time employment guidance teachers act as employment instructors who conduct occupational ability evaluation, simulation of interview and career development counseling on students through employment guidance class, case and group counseling and help students to solve confusions in the employment process.

(III) Implementation measures of full-course developmental employment guidance mode

1. Strengthen the course construction of Employment Guidance for College Students and its educational effect

Course construction is the key point in the implementation process of full-course developmental employment guidance mode. Employment Guidance for College Students should be included in talent training program, teaching plan and teaching schedule. Course objectives, course system, teaching contents and methods should be adjusted in time according to school-running orientation, professional features and students' demands and equal importance should be attached to teaching management and supervision, teaching evaluation, teaching research and reform and specialized courses. Employment Guidance for College Students pays attention to the guidance of students' concepts, self-exploration and implementation of actions through scientific teaching design and arrangement, systematic teaching and classroom experience and interaction. Employment guidance course can be set up respectively for freshmen, junior students and senior students. Professional career planning course set up for freshmen can help students adapt to college life and conduct vocational education and guidance on professional career. Theoretical teaching contents and entrepreneurial guidance contents of employment guidance course should be set up for junior students and practical teaching contents of employment guidance course should be set up for senior students.

\section{Set up career guidance workshop and assist students in career development through point-plane combination}

Guidance and consultation are the most important forms of employment guidance. Career guidance workshops conduct individual consultation and group guidance and implement the work of employment guidance. It is required to establish career guidance workshops, supply professional teachers, corresponding career assessment tools and quality development training equipment and conduct individual consultation and group guidance; adopt "one-to-one" individual consultation, use the method of psychological consultation and career consultation and help students define their own vocational interests, occupational value and vocational character and conduct scientific and rational career planning and career decision-making. In group guidance, vocational counselors lead students to participate in, experience and share career growth process and explore problems in professional career, seek for blind spots and expand ideas with the use of career counseling and psychological counseling concepts through activities, discussion and interview. Group guidance 
pays attention to allow participants to change and grow up in a good atmosphere with the support and power of team.

\section{Strengthen employment recommendation and promote the effect of employment work with information networking construction}

The combination of traditional media and new media is a good choice to ensure that employment information can be transferred to students in time and effectively. Traditional media such as school magazine and newspaper, campus broadcasting, mobile phone, employment brochure and report of excellent schoolfellows and employment information networking construction should be strengthened. Employment recommendation includes the construction of three systems: graduate information system, job application information system and employment information distribution system. Graduate information system includes the collection and organization of personal information of graduates, including name, gender, height, major, specialty and employment will, thus forming a strong database for the convenience of consultation and recommendation of academic advisors and employers. It is also basic data for later employment tracking of graduates. Employment information system includes the collection and distribution of employment information. All teachers work together, go deep into employers actively for the collection of employment information and create as more employment choices as possible for students' employment. In information distribution system, computer terminal sends employment information to the mobile phone of each graduate, thus transferring employment information in time and effectively.

(III) Implementation mode: combination of daily activities and centralization, full time and part time, on-campus and off-campus activities

The implementation mode of full-course developmental employment guidance mode depends on the following combination: first, combination between daily career guidance counseling and full-course training in the second classroom and third classroom and centralized employment guidance course and employment recommendation during graduation, i.e. point-plane combination, which can strengthen the effectiveness of guidance; second, combination between full-time employment instructors and part-time academic tutors and internship instructor, i.e. establishment of a professional team combining professionalism and specialization; third, combination between on-campus employment guidance and off-campus probation and internship and combination between on-campus employment instructors and off-campus industry instructors.

In conclusion, applied undergraduate colleges should promote scientific development, train applied technical and skilled talents adapting to social development needs, attach great importance to employment guidance for college students and provide college students with refined employment guidance adapting to their growth and meeting their individual needs under the increasingly severe employment pressure. Full-course developmental employment guidance mode is an effective attempt and exploration.

\section{Acknowledgments}

This paper is 2014 school-level educational reform subject of Chongqing University of Education "Establishment and Practice of Employment Guidance Course System of Applied Undergraduate Colleges”, subject No. JG2014230.

\section{References}

1. Wen Hourun, Zhang Bin. Practical Course for Employment of College Students - Career Development and Employment Guidance for College Students [M]. Beijing: Higher Education Press, 2011.

2. Robert C. Reardon, Janet G. Lenz, James P. Sampson, hr. , Gary W. Peterson. Professional Career Development and Rules [M]. Beijing: China Renmin University Press, 2010.

3. Zhai Bo. Establishment and Implementation Choice of "Full-course" Employment Guidance Mode of Colleges and Universities [J]. Modern Education Management, 2011, (11):111-114. 